\title{
The BCL-2 arbiters of apoptosis and their growing role as cancer targets
}

\author{
Jerry M Adams ${ }^{\star, 1,2}$ and Suzanne Cory ${ }^{\star, 1,2}$
}

Impaired apoptosis plays a central role in cancer development and limits the efficacy of conventional cytotoxic therapies. Deepening understanding of how opposing factions of the BCL-2 protein family switch on apoptosis and of their structures has driven development of a new class of cancer drugs that targets various pro-survival members by mimicking their natural inhibitors, the BH3-only proteins. These 'BH3 mimetic' drugs seem destined to become powerful new weapons in the arsenal against cancer. Successful clinical trials of venetoclax/ABT-199, a specific inhibitor of BCL-2, have led to its approval for a refractory form of chronic lymphocytic leukaemia and to scores of on-going trials for other malignancies. Furthermore, encouraging preclinical studies of BH3 mimetics that target other BCL-2 pro-survival members, particularly MCL-1, offer promise for cancers resistant to venetoclax. This review sketches the impact of the BCL-2 family on cancer development and therapy, describes how interactions of family members trigger apoptosis and discusses the potential of $\mathrm{BH} 3$ mimetic drugs to advance cancer therapy.

Cell Death and Differentiation (2018) 25, 27-36; doi:10.1038/cdd.2017.161; published online 3 November 2017

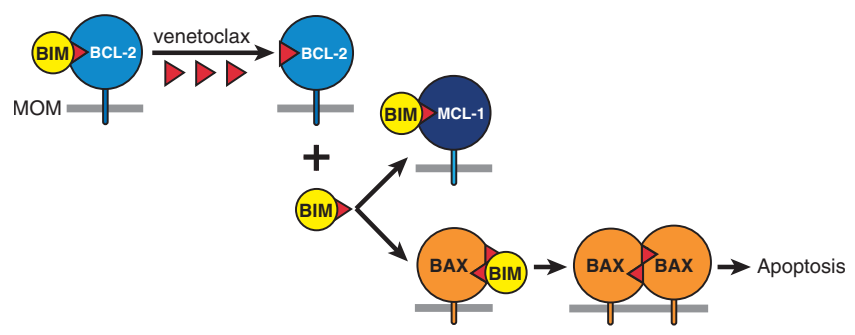

Graphical Abstract

In many tumour cells, a pro-survival protein like BCL-2 is occupied on the mitochondrial outer membrane (MOM) by a $\mathrm{BH} 3-$ only protein such as BIM. The BCL-2-specific $\mathrm{BH} 3$ mimetic drug venetoclax can displace BIM from BCL-2 and prevent $B C L-2$ from sequestering active BAX or BAK. Also, the released BIM can neutralise a non-targeted pro-survival protein like MCL-1 and directly activate BAX (or BAK) for oligomerisation and cell death.

\section{FACTS}

- Three factions of the BCL-2 protein family interact to adjudicate whether cells undergo apoptosis. The process is initiated when BH3-only proteins, upregulated by diverse stress signals, engage the surface groove of pro-survival relatives (for example, BCL-2, BCL- $\mathrm{K}_{\mathrm{L}}, \mathrm{MCL}-1$ ), preventing their constraint of $\mathrm{BAX}$ and $\mathrm{BAK}$, which then form oligomers that perforate the outer mitochondrial membrane to elicit caspase activation.

- Diverse tumours have defects in activation of apoptosis because of overexpression of BCL-2 pro-survival proteins or impaired upregulation of $\mathrm{BH} 3$-only proteins due to, for example, inactivation of the p53 pathway.
- As a new approach to cancer therapy, drugs termed ' $\mathrm{BH} 3$ mimetics' that tightly bind the surface groove of certain prosurvival BCL-2 proteins have been developed.

- Venetoclax, a potent BCL-2-specific BH3 mimetic, has been approved for treatment of a refractory form of chronic lymphocytic leukaemia and is under trial for many other malignancies, both as a single agent and in combination with diverse known anticancer agents.

- Genetic data and preclinical studies predict that recently developed $\mathrm{BH} 3$ mimetics specifically targeting MCL-1 will be efficacious against multiple haemopoietic malignancies and sensitise some solid tumours to other agents.

\section{OPEN QUESTIONS}

- As certain normal cell populations are sensitive to diminished levels of BCL- $X_{L}$ or MCL-1, can an acceptable therapeutic window be found for their inhibitors?

- Given that most current trials of $\mathrm{BH} 3$ mimetics have focussed on haemopoietic malignancies, will the new drugs also have a major role in treating solid tumours?

- Which combinations of BH3 mimetics, either with each other or with other targeted or conventional agents, will be most efficacious for different malignancies?

- Can BH3 mimetic therapy provide protracted remissions without the need for long-term treatment?

- Will increased understanding of BAX and BAK oligomers and the elusive apoptotic pore suggest additional ways to target the apoptotic switch for cancer therapy?

The FDA approval in 2016 of venetoclax (also known as ABT-199) for treating a refractory form of chronic lymphocytic

${ }^{1}$ The Walter and Eliza Hall Institute of Medical Research, Parkville, VIC 3052, Australia and ${ }^{2}$ Department of Medical Biology, University of Melbourne, Parkville, VIC 3052 , Australia

${ }^{*}$ Corresponding author: JM Adams or S Cory, The Walter and Eliza Hall Institute of Medical Research, Parkville, VIC 3052, Australia. Tel: +61 393452491 ; Fax: +61 39347 0852; adams@wehi.edu.au or cory@wehi.edu.au

Received 08.6.17; revised 30.7.17; accepted 31.8.17; Edited by F Pentimalli; published online 03.11.17 
leukaemia (CLL) was a significant milestone for cancer research and therapy. The remarkable clinical performance of this drug, designed to mimic natural triggers of apoptosis, capped three decades of research on the BCL-2 protein family. In this review, we reflect on the discovery of BCL-2 and its relatives, summarise how they regulate apoptosis and describe how this knowledge drove the development of $\mathrm{BH} 3$ mimetic anticancer drugs. We then sketch the clinical findings that led to FDA approval of venetoclax and discuss its potential and that of other emerging $\mathrm{BH} 3$ mimetics, particularly those targeting MCL-1. In addition to the articles in this series, ${ }^{1-6}$ other recent reviews assess the clinical impact of $\mathrm{BH} 3$ mimetics and BCL-2 family function. ${ }^{7-10}$

\section{Apoptosis and its first known inhibitor: BCL-2}

In vertebrates, apoptosis both shapes the embryo and ensures homeostasis within adult tissues. During apoptosis, cells shrink, fragment their DNA, bleb and break up into 'apoptotic bodies' for engulfment by phagocytes. ${ }^{11}$ Importantly, because the plasma membrane is not breached, no inflammation ensues. Apoptosis culminates in activation of cysteine proteases called caspases that cleave vital cellular proteins. Caspases are activated through either the 'extrinsic' apoptosis pathway, triggered by engagement of cell surface 'death receptors' of the tumour necrosis factor (TNF) receptor family, or the 'intrinsic' pathway, initiated by diverse cellular stresses. The BCL-2 protein family regulates the latter, by controlling the integrity of the mitochondrial outer membrane (MOM).

BCL-2 was the first inhibitor of apoptosis to be discovered, in any species. The gene was found linked to the immunoglobulin heavy chain gene locus by the $t(14 ; 18)$ chromosome translocation that hallmarks human follicular lymphoma (FL). ${ }^{1}$ Although BCL-2 seemed likely to be a new oncoprotein, its sequence provided no clues about its function. In 1988, Vaux et al. ${ }^{12}$ solved the mystery by showing that lymphocytes forced to express elevated $\mathrm{BCL}-2$ resisted apoptosis when deprived of their requisite cytokine. This seminal study revealing BCL-2 as the prototypic inhibitor of cell death also established, for the first time, that cytokines signal cell survival and proliferation by different pathways and that impaired apoptosis contributes to malignant transformation.

$B C L-2$ transgenic mice reinforced and extended these observations. The excess lymphocytes they accumulated had failed to die in response to physiological cues and resisted diverse cytotoxic agents, including chemotherapeutic drugs. $^{13-16}$ Notably, mice co-expressing BCL-2 and myc transgenes developed lymphomas markedly faster than littermates expressing either transgene alone, ${ }^{17}$ validating $B C L-2$ as an oncogene. Clarifying the basis for the synergy with myc, enforced MYC expression proved to stimulate apoptosis. ${ }^{18,19}$ Thus, by blocking apoptosis, BCL-2 removes a critical brake on MYC-driven proliferation and oncogenesis.

As $t(14 ; 18)$ translocations can be detected in B cells of healthy humans, ${ }^{20}$ follicular lymphoma requires mutations additional to $B C L-2$ translocation, and perhaps also chronic T-cell stimulation. ${ }^{21}$ Several other human malignancies express elevated BCL-2 because of diverse mechanisms. Notably, the high BCL-2 in CLL reflects loss of microRNAs that normally dampen translation of its messenger RNA. ${ }^{1}$ a

Pro-apoptotic initiators: BH3-only proteins

BIM, BID, PUMA, NOXA, BAD, HRK, BMF, BIK

Pro-survival guardians

BCL-2, BCL-X ${ }_{L}$, BCL-W, MCL-1, A1/BFL-1, BCL-B

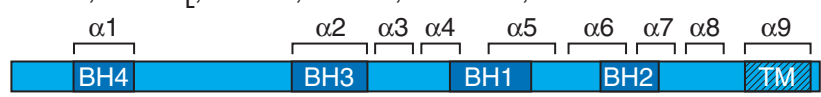

Pro-apoptotic effectors

BAX, BAK, BOK?

\begin{tabular}{|c|c|c|c|c|}
\hline$\alpha 1$ & $\alpha 2$ & م3 & $\alpha 6 \quad \alpha 7 \quad \alpha 8$ & $\alpha 9$ \\
\hline BH4 & $\mathrm{BH} 3$ & $\mathrm{BH} 1$ & $\mathrm{BH}_{2}$ & 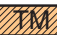 \\
\hline
\end{tabular}

b

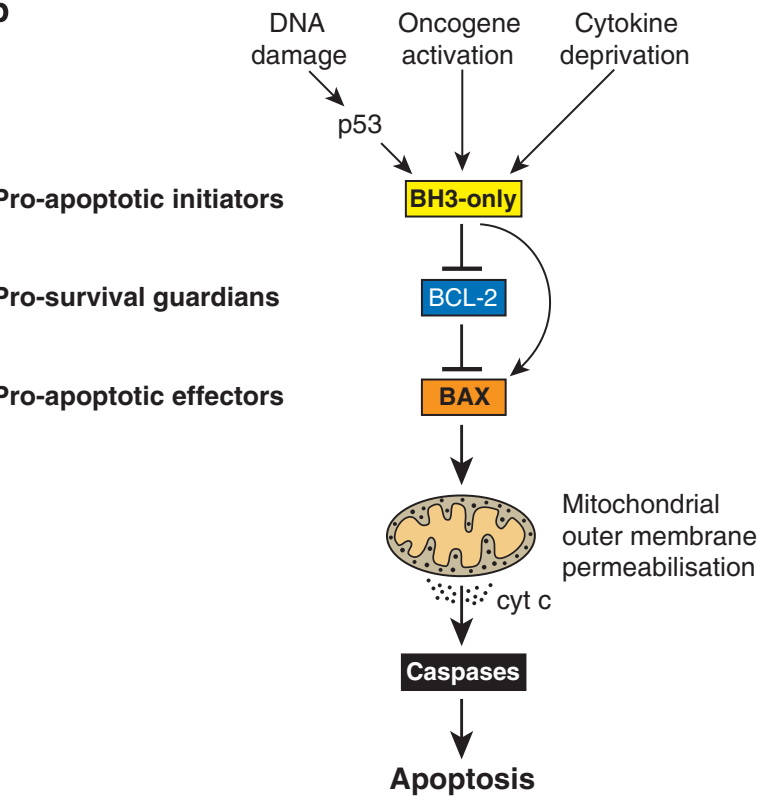

Figure 1 The BCL-2 protein family. (a) The initiator, guardian and effector factions of the family. Domains of shared BCL-2 Homology (BH), and the nine $\alpha$-helices in the multi-BH domain members are indicated. (Effectors BAX and BAK, and the related $\mathrm{BOK}$, have a $\mathrm{BH} 4$ domain if both structural and sequence homology are considered. ${ }^{29}$ ) BOK seems to drive apoptosis only in special circumstances. ${ }^{6}$ Faction members most important for controlling apoptosis are in bold. All multi-BH domain family members and some BH3-only proteins (BIM, BID, BIK, HRK) have a C-terminal transmembrane (TM) domain for anchoring to organelles, most notably the MOM. (b) How the BCL-2 protein family controls cell life and death is shown. In healthy cells, the pro-survival guardians prevent activation of BAX and BAK, at least in part by binding the $\mathrm{BH} 3$ domain $(\alpha 2)$ of any destabilised BAX or BAK monomers. Various stress signals activate BH3-only proteins that avidly bind their pro-survival relatives, preventing their constraint of BAX or BAK. In addition, certain BH3-only proteins, namely BIM, cleaved (active) BID and probably PUMA, can directly activate $\mathrm{BAX}$ and BAK, which then homo-oligomerise and permeabilise the MOM, releasing cytochrome $c$ to initiate caspase activation and cellular demolition. Modified, with permission, from Figure 1 of Cory et al. ${ }^{8}$

\section{The BCL-2 protein family}

Vertebrate proteins related to BCL-2 bear from one to four $B C L-2$ Homology $(\mathrm{BH})$ domains and fall into three functional factions (Figure 1a). The closest BCL-2 relatives $\left(B C L-X_{L}\right.$, BCL-W, MCL-1, A1/BFL-1 and, in humans, BCL-B) promote cell survival, but BAX and BAK (and possibly BOK) instead promote cell death, as do distant relatives termed $\mathrm{BH} 3$-only 
a

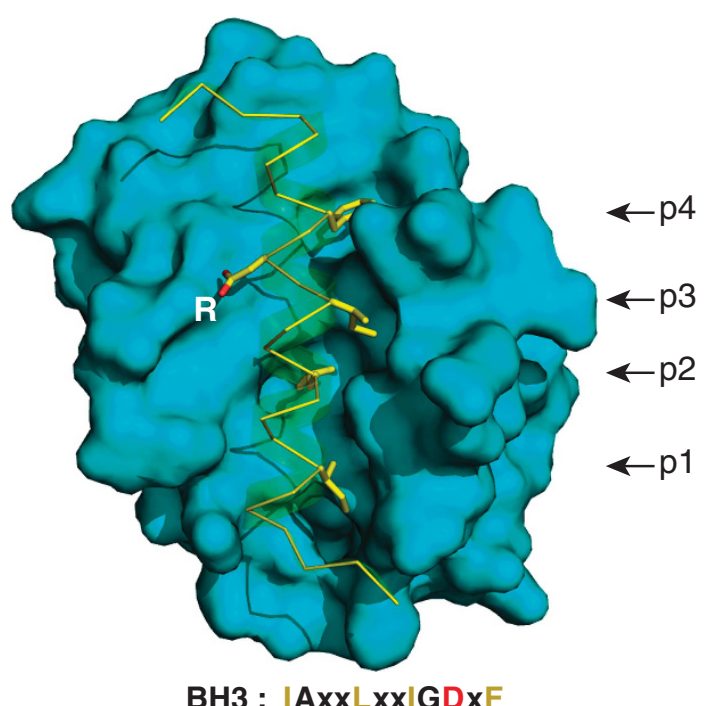

b

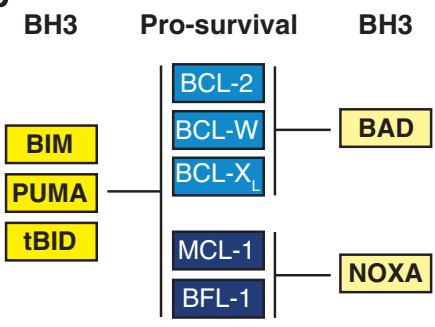

c

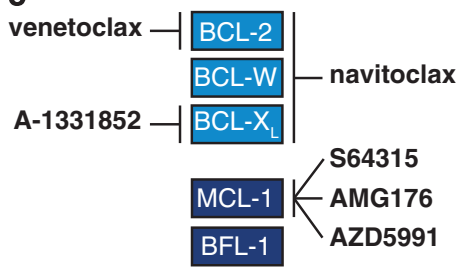

Figure 2 Interaction of $\mathrm{BCL}-2$ family members. (a) The canonical $\mathrm{BH} 3 /$ surface groove interaction in the family. Structure of $\mathrm{BCL}-\mathrm{X}_{\mathrm{L}}$ (blue surface representation) bound to the amphipathic helical BH3 peptide of BIM (a yellow ribbon indicates its helical structure) ${ }^{27}(\mathrm{PDB} / 3 \mathrm{FDL})$, with its N terminus at the bottom. Underneath the protein is a consensus $\mathrm{BH} 3$ sequence of the pro-apoptotic proteins ( $\mathrm{x}$ denotes nonconserved residues). The four key hydrophobic amino acids (yellow) of the Bim BH3 peptide that bind to pockets p1 to p4 in BCL- $X_{L}$ are highlighted, as is the invariant aspartic acid (D) (oxygens in red) that binds to a conserved arginine (R) in BCL- $X_{L}$. BIM or BID BH3 peptides associate with the grooves of BAX or BAK through contacts resembling those with their pro-survival relatives (as above) but include additional contacts that contribute to their activator function. ${ }^{41-44}$ (b) Selective association of BH3-only proteins with their pro-survival relatives. Whereas BIM, PUMA and tBID bind promiscuously, BAD and NOXA have restricted targets, as indicated. (c) BCL-2 pro-survival targets of current $\mathrm{BH} 3$ mimetic drugs. $\mathrm{A} \mathrm{BH} 3$ mimetic engages the surface groove of the targeted pro-survival protein(s) in a manner akin to their natural antagonists, as in (a), but usually involving only pockets $\mathrm{p} 2$ and p4. In cells, binding of the compound to their pro-survival target(s) releases any bound BH3-only proteins and prevents the targeted pro-survival protein(s) from restraining BAX and BAK. Note that preclinical studies were reported on Servier MCL-1 inhibitor S63845, ${ }^{115}$ but the clinical candidate from Novartis/Servier is the more advanced derivative S64315. Modified, with permission, from Figure 2 of Cory et al. ${ }^{8}$

proteins, because their only homology to BCL-2 (or each other) is the $\mathrm{BH} 3$ domain, through which they engage multi-BH domain relatives.

Interactions between these factions determine whether cells live or die (Figure 1b). In healthy cells, pro-survival proteins prevent apoptosis by sequestering any activated prodeath relatives. However, upon diverse cellular stresses (e.g., cytokine or nutrient deprivation, DNA damage or oncogene activation), $\mathrm{BH} 3-$ only proteins are upregulated and avidly bind the pro-survival proteins, preventing their constraint of BAX and BAK. In addition, certain $\mathrm{BH}$-only proteins, particularly BIM and BID and probably PUMA, can directly activate BAX and $\mathrm{BAK}$, prompting their homo-oligomerisation and $\mathrm{MOM}$ permeabilisation. Cytochrome $c$ then leaks into the cytosol, where it helps form the apoptosome that activates caspase-9. In turn, caspase- 9 activates effector caspases 3, 6 and 7 that cleave vital cellular proteins, ensuring cellular demolition.

Curiously, despite the evolutionary conservation of many players, cell death regulation differs significantly between invertebrates and vertebrates. ${ }^{2}$ Thus, the worm Caenorhabditis elegans has a BCL-2 homologue (CED-9) and a BH3-only antagonist (EGL-1) but no BAX/BAK homologue, and CED-9 does not act by maintaining mitochondrial integrity. Furthermore, Drosophila BCL-2-related genes have only minor roles in fly cell death.

Critical roles of vertebrate family members. Gene ablation revealed that the widely expressed BAX and BAK are functionally redundant, apoptosis requiring one or the other. ${ }^{22}$
In contrast, individual pro-survival proteins vary in abundance in different cell types, producing differential dependencies. ${ }^{3,23}$ For example, BCL-2 is crucial for survival of circulating lymphocytes; $B C L-X_{L}$ for neurons, erythroid cells and platelets; and MCL-1 for many haemopoietic (and other) cell types, including stem and progenitor cells. The $\mathrm{BH} 3-$ only proteins, which are regulated by multiple mechanisms, mediate the responses to various cytotoxic insults. ${ }^{23,24}$ For example, whereas DNA damage upregulates p53 protein, which induces expression of PUMA and NOXA, cytokine deprivation relies mainly on BIM and PUMA. ${ }^{23}$ Just as the pro-survival proteins are oncoproteins, several $\mathrm{BH} 3-$ only proteins can be tumour suppressors. ${ }^{23-25}$

Rules of engagement between factions. As first found for $\mathrm{BCL}-\mathrm{X}_{\mathrm{L}},{ }^{26,27}$ all multi-BH domain family members comprise a globular bundle of nine $a$-helices, and all display a hydrophobic surface groove created largely by the conserved $\mathrm{BH} 1, \mathrm{BH} 2$ and $\mathrm{BH} 3$ domains. ${ }^{10,28,29}$ In contrast, most $\mathrm{BH} 3$-only proteins are intrinsically unstructured until their $\mathrm{BH} 3$ domain forms an amphipathic helix upon engagement of a multi-BH domain partner. The exception is BID, which resembles a multi-BH domain protein and requires cleavage to expose its $\mathrm{BH} 3$ domain. ${ }^{29}$

The canonical interaction between family members is the binding of the $\mathrm{BH} 3$ domain of a $\mathrm{BH} 3-$ only protein, or of $\mathrm{BAX}$ or $B A K$, to the surface groove of a multi-BH domain protein (either pro-survival or pro-apoptotic). ${ }^{30}$ As Figure 2a illustrates for a BIM BH3 peptide bound to BCL- $X_{L}$, four conserved $B H 3$ 


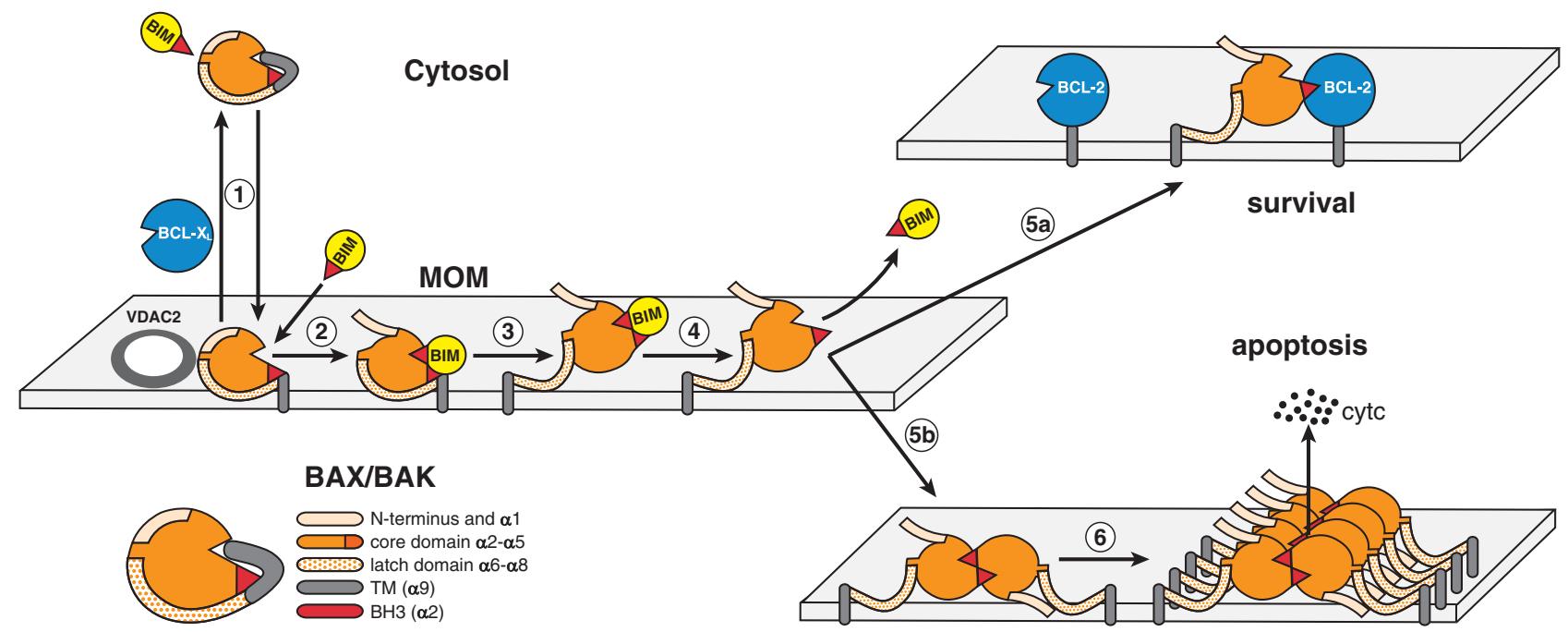

Figure 3 Model for life/death decisions on the MOM, showing how pro-survival family members constrain BAX (and BAK) and how BH3-only proteins (here BIM) drive their activation. In healthy cells, monomeric BAX shuttles between the cytosol and MOM, where VDAC2 acts as a receptor (also for BAK), although pro-survival relatives (here BCL- $X_{L}$ ) can 'retro-translocate' MOM-bound BAX back to the cytosol. ${ }^{36}$ Upon apoptotic signalling, to allow more BAX to move to the MOM (step 1), where most BAK molecules reside, an activator BH3-only protein such as BIM may transiently engage a BAX 'rear site' involving helices $\alpha 1$ and $\alpha 6,{ }^{130,131}$ thereby releasing the $\mathrm{C}$-terminal trans-membrane (TM) domain $(\alpha 9)$ from its surface groove to enable MOM binding. Then, groove binding by the activator drives release of the N terminus and $\alpha 1$ of BAX or BAK (pale orange) (step 2) and all subsequent activation steps for both the MOM-bound effector proteins. The most dramatic change is the unfolding of BAX and BAK that separates their 'latch' domain $\left(\alpha 6-\alpha 8\right.$; speckled orange) from their 'core' domain $(\alpha 2-\alpha 5)^{41,43}$ (step 3); this ejects the BH3-only activator (BIM here) and exposes the BH3 domain of BAX or BAK $(\alpha 2$, red triangle) (step 4). If pro-survival proteins are available to bind the exposed BAX (or BAK) BH3 domain, apoptosis aborts (step 5a). However, if pro-survival proteins are largely occupied by BH3-only proteins, the unfolded BAK or BAX monomers form homodimers through reciprocal BH3/groove interactions of their core domains (step 5b). ${ }^{41,43,46,47}$ The core dimers are the central unit of the BAX and BAK homo-oligomers, ${ }^{46,47,132}$ but how they associate into oligomers (step 6) remains uncertain, as does how the oligomers drive MOM permeabilisation (see text). Modified, with permission, from Figure 3 of Cory et al. ${ }^{8}$

hydrophobic residues project into hydrophobic groove pockets p1-p4, and a BH3 aspartic acid (D) pairs with an adjacent conserved arginine $(\mathrm{R})$ in the groove.

BH3-only proteins vary in affinity for different pro-survival relatives ${ }^{31-33}$ because of sequence differences within both the $\mathrm{BH} 3$ domain and groove ${ }^{29}$ Whereas BIM, PUMA and cleaved BID (tBID) avidly bind all five pro-survival relatives, BAD binds only $B C L-2, B C L-X_{L}$ and $B C L-W$, and NOXA engages only MCL-1 or A1/BFL-1 (Figure 2b). BH3-only proteins that bind all pro-survival proteins (BIM, PUMA, tBID) are more potent killers than those with restricted binding profiles. Importantly, however, NOXA plus BAD kills potently, suggesting that efficient killing requires neutralisation of all pro-survival members in the relevant cell type. ${ }^{32}$

The $\mathrm{BH} 3$ domains of activated BAX and BAK also show preferences: $B A K$ is restrained primarily by $B C L-X_{L}, M C L-1$ and $A 1 / B F L-1,{ }^{34}$ whereas $B A X$ is controlled by all pro-survival members. ${ }^{35}$

The outcome of $\mathrm{BH} 3$ domain binding differs dramatically between a pro-survival and a pro-apoptotic multi-BH domain protein. The $\mathrm{BH} 3$ complexes with pro-survival proteins are stable, whereas those with BAX or BAK are fleeting and elicit remarkable conformational changes, as detailed below.

\section{The life/death switch on the MOM}

In healthy cells, pro-survival and pro-apoptotic multidomain proteins are distributed between the cytosol and intracellular membranes, with the MOM being the primary site regulating apoptosis. Whereas BCL-2 and BAK are predominantly integral
MOM proteins, BAX is mainly cytosolic, with its hydrophobic tail (a9) partially sequestered in its groove. ${ }^{28}$ Apoptotic cues lead to release of $a 9$, which attracts BAX to the MOM, although it can be 'retro-transposed' back to the cytosol by pro-survival proteins like $B C L-X_{L} \cdot{ }^{36}$ BAK behaves similarly, but its equilibrium strongly favours MOM insertion. ${ }^{37}$ Both BAX and BAK initially associate with the MOM in a large complex with VDAC2, ${ }^{38-40}$ a minor isoform of the voltage-dependent anion channel that mediates nutrient and ion transport through the MOM.

The switch from survival to apoptosis is triggered when $\mathrm{BH} 3-$ only proteins reach concentrations sufficient to both neutralise their pro-survival relatives and activate BAX or BAK, culminating in $\mathrm{BAX} / \mathrm{BAK}$ homo-oligomerisation and MOM pore formation. Direct activator $\mathrm{BH} 3$-only proteins such as BIM and tBID induce multiple conformational changes in BAX and BAK (Figure 3) ${ }^{41-44}$ As well as dislodging the BAX transmembrane domain $(a 9)$ from its surface groove ${ }^{28}$ these include release of the $\mathrm{N}$-terminal segment (including 1 1) of both BAK and BAX. ${ }^{45}$ Then, remarkably, BAX and BAK unfold into an N-terminal 'core' $(a 2-a 5)$ and a C-terminal 'latch' ( $a 6-a 8) .{ }^{41,43}$ This metamorphosis displaces the activating $\mathrm{BH} 3$-only protein and exposes the $\mathrm{BH} 3$ domain of BAX/BAK (a2), creating a critical decision point (Figure 3 ). If pro-survival proteins such as $\mathrm{BCL}-2$ are available to bind the $\mathrm{BH} 3$ domain of activated $\mathrm{BAX} /$ BAK, apoptosis aborts (Figure 3 , upper right). However, if the pro-survival proteins are largely occupied by $\mathrm{BH} 3$-only proteins, the cores of unfolded BAK or BAX monomers instead form homodimers through reciprocal $\mathrm{BH} 3 /$ groove interactions (Figure 3, lower right). ${ }^{41,43,46,47}$ 
Though the evidence is now compelling that direct engagement of BAX or BAK by a BH3-only protein can trigger their activation, this interaction may be catalytic rather than obligatory because in a mammalian cell line engineered to lack all the BCL-2 pro-survival proteins and all BH3-only proteins, BAX and BAK spontaneously engaged the MOM, oligomerised and evoked apoptosis. ${ }^{48}$ Thus, restraint by the pro-survival faction is crucial to prevent unwarranted cell death provoked by BAX and BAK.

The quest for the elusive apoptotic pore. As all mutations impairing BAX or BAK dimerisation impair MOM permeabilisation, ${ }^{46,49}$ BAX/BAK homodimers and probably also the larger homo-oligomers they form must be required. ${ }^{4}$ However, how are the reciprocal dimers linked into oligomers? Although they can be coupled via $a 6,{ }^{50,51} a 3$ and $a 5^{52}$ $a 9^{53,54}$ or $a 1,{ }^{55}$ all these proposed linkages are weaker than those that maintain $\mathrm{BH} 3$ domain-groove dimers, and none as yet appears essential for oligomerisation, prompting a recent proposal that disordered dimer clusters suffice to disrupt the MOM. ${ }^{55}$

Most current apoptotic pore models ${ }^{4,52,55-58}$ suggest that lipids partially wall the pores and that the oligomers do not have a simple structure. Contrary to the long-standing 'umbrella' model in which a BAX $a 5-a 6$ hairpin penetrates the $\mathrm{MOM},{ }^{26,59}$ helices $a 4$ and $a 5$, which form the hydrophobic 'bottom' of the stable BH3/groove dimer, ${ }^{41,43}$ appear to lie 'inplane' with the MOM and sink only into its outer leaflet, as do the flexible $a 6, a 7$ and $a 8$ helices. ${ }^{55,56}$ Their shallow insertion would expand the outer leaflet relative to the inner leaflet, promoting tension that induces a nascent lipidic pore that the dimers or oligomers may stabilise by sliding over the rim. ${ }^{56,58}$ Indeed, in the 'clamp model', a core dimer sits on the rim with its two flexible $a 6-a 8$ 'arms' projecting on the inner and outer leaflets, and the two $a 9$ helices penetrate the bilayer from both faces to stabilise the pore. ${ }^{57}$

High-resolution imaging is beginning to reveal the pores. Cryo-EM showed nanogold-labelled activated BAX edging large pores in liposomes. ${ }^{60}$ Super-resolution microscopy on activated BAX in mitochondria also revealed large arcs and rings, ${ }^{61,62}$ indicative of pores, ${ }^{62}$ and atomic force microscopy of lipid bilayers revealed heat-activated BAX oligomers around huge holes $20-80 \mathrm{~nm}$ in diameter. ${ }^{61}$ Lining such rings might require $>40 \mathrm{BAX}$ dimers. However, these studies cannot distinguish a fully BAX-lined pore from a partially lipidic rim braced by BAX helices. Irrespective, it seems that BAX oligomers expand limitlessly rather than forming a pore of defined, or even preferential, size.

\section{Rationale for $\mathrm{BH} 3$ mimetic anticancer drugs and their development}

Many tumours, especially those refractory to therapy, express elevated levels of one or more pro-survival family member, ${ }^{7,63}$ and many carry mutations that cripple induction of $\mathrm{BH} 3-$ only proteins. In particular, most tumours ( $90 \%)$ have mutations that inactivate the p53 protein, delete its gene or impair upstream regulators, preventing p53 induction of PUMA and NOXA to drive apoptosis. ${ }^{64}$ In addition, $17 \%$ of mantle cell lymphoma cell lines have homozygous deletions of $B I M,{ }^{65}$ and many Burkitt lymphomas harbour epigenetically silenced BIM or PUMA alleles. ${ }^{66,67}$

Although such changes can make cancer cells resistant to cytotoxic agents, including radiation and chemotherapeutics, most tumours retain the core apoptotic machinery, suggesting that organic molecules mimicking $\mathrm{BH}$-only proteins might switch on apoptosis. However, the long, shallow and primarily hydrophobic groove of the pro-survival proteins made the challenge daunting. Indeed, most of the putative $\mathrm{BH} 3$ mimetics initially reported had relatively modest affinity for pro-survival proteins and few passed the definitive test of requiring $B A X$ or $B A K$ to kill cells. ${ }^{68,69}$

The first bona fide $\mathrm{BH} 3$ mimetic, ABT-737, was developed by Abbott Laboratories (now AbbVie) in a decade-long tour de force using NMR fragment screening, structural biology and medicinal chemistry to enhance affinity and reduce serum binding. $^{70}$ Like the BH3-only protein BAD (Figure $2 b$ ), ABT-737 has low nanomolar affinity for BCL-2, BCL- $X_{L}$ and $B C L-W$ but negligible affinity for $M C L-1$ or $A 1 / B F L-1$, as does the orally bioavailable derivative navitoclax (ABT-263) developed for the clinic. ${ }^{71}$ The crystal structures of $B C L-X_{L}$ binding $\mathrm{ABT}-737^{72}$ and $\mathrm{BCL}-2$ binding $\mathrm{ABT}-263^{73}$ revealed intriguing differences to their complexes with a natural ligand like BIM. ${ }^{27}$ Although two hydrophobic moieties of the compounds engage the p2 and p4 groove hydrophobic pockets (Figure 2a), the p2 pocket is penetrated much more deeply than by the BIM invariant $\mathrm{BH} 3$ leucine, revealing unanticipated groove plasticity.

Because BCL- $X_{L}$ controls platelet lifespan, ${ }^{74}$ ABT-737 and navitoclax provoke acute dose-limiting thrombocytopaenia. ${ }^{75,76}$ Efforts to circumvent this problem led to the development of the BCL-2-specific venetoclax $(A B T-199)^{73}$ that spares platelets. ${ }^{73,77}$ Venetoclax differs from navitoclax primarily by engaging the $\mathrm{p} 4$ pocket in a manner that exploits a difference between BCL-2 (Asp103) and BCL-X (Glu96). $^{73}$

Other $\mathrm{BH} 3$ mimetics are emerging. ${ }^{9}$ They include another BCL-2-specific inhibitor (Servier's S55746); the BCL- $\mathrm{X}_{\mathrm{L}^{-}}$ specific WEHI-53978 and its more potent derivatives $\mathrm{A}-1155463$ and $\mathrm{A}-1331852 ;{ }^{79}$ and, most recently, three MCL-1-specific inhibitors (see below) (Figure 2c).

Many tumour cells are primed to die. Paradoxically, many tumours with elevated levels of a pro-survival protein are nonetheless sensitive to cytotoxic therapies, including $\mathrm{BH} 3$ mimetics. Indeed, they seem 'primed to die', that is, more sensitive than their normal counterparts. ${ }^{5,80}$ The basis of priming appears to be that the mutations and stresses suffered by a cell en route to malignancy upregulate $\mathrm{BH}$-only proteins such as BIM, imposing selective pressure for elevated levels of pro-survival proteins. Consequently, prosurvival proteins loaded with potent $\mathrm{BH} 3-$ only proteins like BIM put the cells in many tumours on the brink of apoptosis (Figure 4). ${ }^{81}$ This concept explains how a cancer cell with elevated BCL-2 can be more susceptible to apoptosis than a normal cell with lower BCL-2.

Notably, in a primed tumour cell, the impact of a $\mathrm{BH} 3$ mimetic can extend beyond the targeted protein. Thus, in Figure 4, although venetoclax targets only BCL-2, the BIM it frees from $B C L-2$ can engage the non-targeted $M C L-1$ or $B A X$ or BAK, enhancing sensitivity. ${ }^{5,81,82}$ Priming, which can be 


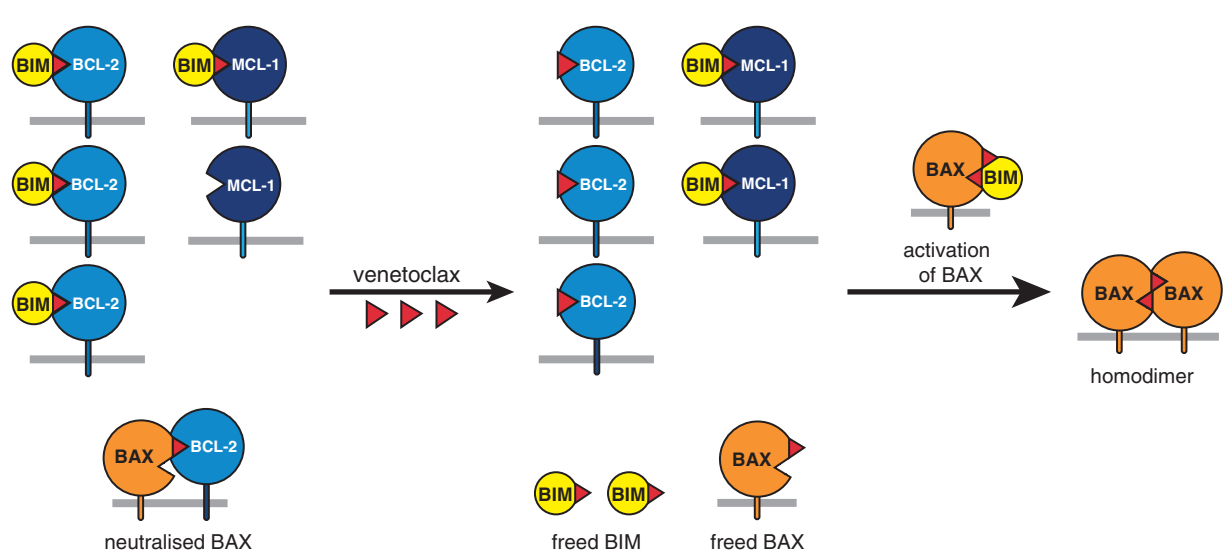

Figure 4 Killing of 'primed' cancer cells by BH3 mimetics. Because of the many stresses imposed by the tumourigenic process, such as abridged cell cycle checkpoints, hypoxia or altered metabolism, many cancer cells have been selected for elevated expression of pro-survival proteins, here BCL-2 and MCL-1. These stresses will have elevated the level of BH3-only proteins such as BIM, much of which may be in complex with BCL-2 (top left). Hence, paradoxically, the 'primed' cancer cell, despite elevated BCL-2, can be nearer the apoptotic threshold than normal cell counterparts. ${ }^{80}$ (see text and Letai ${ }^{5}$ in this series.) When such cells are exposed to a BCL-2-specific BH3 mimetic like venetoclax (red triangles), BIM is displaced from BCL-2, as is any BAX previously sequestered by BCL-2 (bottom left). The freed BIM can then sequester any unoccupied non-targeted prosurvival protein (here MCL-1) (centre); it can also activate inactive BAX (or BAK) monomers (right), thereby facilitating apoptosis. Thus, the presence in a primed cancer cell of abundant complexes of a BH3-only protein like BIM with a pro-survival partner renders the cell more vulnerable to apoptosis. Once activated BAX monomers build up on the MOM, each can insert its exposed BH3 $(\alpha 2)$ into the groove $(\alpha 3-\alpha 5)$ of another activated monomer, generating a 'symmetric' homodimer (right). ${ }^{41,43,46}$ These dimers can then oligomerise and permeabilise the MOM, releasing cytochrome $c$ (cyt $c$ ) from the intermembrane space to trigger caspase activation (see Figure 3). Modified, with permission, from Figure 5 of Cory et al. ${ }^{8}$

assessed by the sensitivity of mitochondria in permeabilised cells to disruption by $\mathrm{BH} 3$ peptides, often correlates with responses to cytotoxic chemotherapy. ${ }^{83,84}$

Unexpectedly, unlike malignant and neonatal tissues, many normal adult tissues (particularly brain, heart, kidney) are refractory to both $\mathrm{BH} 3$ mimetic and conventional cytotoxic therapies because their apoptotic systems are enfeebled, in part by a dearth of BAX and BAK. ${ }^{85}$

\section{The therapeutic potential of $\mathrm{BH} 3$ mimetics}

Navitoclax trials show promising efficacy: Navitoclax was the first authentic $\mathrm{BH} 3$ mimetic to enter clinical trials, after extensive preclinical studies on ABT-737 and navitoclax had established their efficacy and mechanism of action. ${ }^{68,70,71,86}$ Navitoclax proved active in malignancies with high BCL-2, such as CLL and FL. ${ }^{75}$ Although the predicted rapid drop in platelets ${ }^{74}$ precluded determining the maximal response rate, circulating tumour cells were reliably reduced in CLL and $35 \%$ of patients had an objective response. ${ }^{75}$ Although responses in FL were very limited, combining navitoclax with the CD20 antibody rituximab proved safe and markedly improved response rates in both CLL and FL. ${ }^{87}$

Venetoclax: the first $\mathrm{BH} 3$ mimetic to enter routine clinical practice: The accelerated FDA approval of venetoclax followed highly encouraging phase $1^{88}$ and phase $2^{89}$ clinical trials indicating that daily oral venetoclax is effective against relapsed and refractory CLL, including disease resistant to DNA-damaging chemotherapy and having poor prognostic features. Indeed, some of these patients had exhausted all other credible treatment options. Of those receiving therapeutically effective levels (150 to $1200 \mathrm{mg} /$ day), $79 \%$ had an objective clinical response and $20 \%$ a complete remission. ${ }^{88}$ Like navitoclax, ${ }^{75}$ venetoclax evoked canonical apoptosis features in CLL cells, verifying the mechanism of action. ${ }^{90}$ $\mathrm{BH} 3$ mimetics act downstream of p53 (Figure 1b) and, as expected, their efficacy proved independent of p53 status. ${ }^{75,88-90}$ The high response rate in CLL patients with deletion $17 p^{89}$ considerably exceeded those obtained previously for combinations of monoclonal antibodies and chemotherapy. ${ }^{88}$ Thus, venetoclax significantly advances CLL therapy. ${ }^{5}$

In the first venetoclax trial, the precipitous tumour decimation in several CLL patients with a large tumour burden provoked tumour lysis syndrome, ${ }^{88}$ which arises when tumour destruction exceeds the body's capacity to remove cell debris. This potentially fatal syndrome is now avoided by ramping up the dosage over a month, from a low level to the target dose. ${ }^{88}$ Other toxicities include mild gastrointestinal side effects and neutropaenia, both of which can be well managed clinically. ${ }^{88}$

Other B lymphomas with high BCL-2 that respond to venetoclax as a single agent include mantle cell lymphoma and, less frequently, follicular lymphoma, myeloma and some diffuse large B-cell lymphomas. ${ }^{91}$ Responses in $\mathrm{FL}$ and myeloma often required higher doses than in CLL, probably because MCL-1 and BCL- $X_{L}$ are more abundant than in CLL. ${ }^{92}$ Relapsed or refractory acute myeloid leukaemia (AML) has also shown modest single agent responsiveness (19\%). ${ }^{93}$

Venetoclax sensitises to other therapies: Preclinical data ${ }^{73,79,94,95}$ predict that rational combination therapies should greatly boost the clinical impact of venetoclax. Accordingly, in CLL and B-cell lymphomas, venetoclax is under trial with anti-CD20 antibodies, with or without genotoxic chemotherapy; in CLL and mantle cell lymphoma, with ibrutinib that inhibits Bruton's tyrosine kinase; and in multiple myeloma, with proteasome inhibitor bortezomib and steroids (see https:// clinicaltrials.gov/ct2/results?term = venetoclax).

The most advanced available data are from venetoclax plus rituximab in relapsed CLL. Exciting results indicate an $86 \%$ response rate and complete remissions in 51\%, over twice that with venetoclax alone. ${ }^{96}$ Moreover, in $80 \%$ of complete 
responders and $57 \%$ of all treated patients, the bone marrow exhibited no minimal residual disease. Notably, all 11 patients without minimal residual disease who stopped treatment remain progression free, ${ }^{96}$ raising the exciting prospect of protracted remissions without continuous venetoclax therapy.

Venetoclax combination therapy should have important applications beyond lymphoid malignancies. Clinical trials in treatment-naive AML with venetoclax plus demethylating agents (decitabine or azacitidine) have yielded highly promising preliminary results, including $38 \%$ complete remissions. ${ }^{97}$ Furthermore, in preclinical AML models, targeting both BCL-2 and $M C L-1$ eradicated disease, and venetoclax synergistically enhanced the activity of cytarabine and idarubicin. ${ }^{98}$ Similarly, AML cells with mutated isocitrate dehydrogenase 1 or 2 are BCL-2 dependent, and preclinical studies showed that this AML subset was sensitive to venetoclax plus agents that disrupt mitochondrial electron transport. ${ }^{99}$

Although inhibitors of the BCR-ABL kinase, for example, nilotinib, have revolutionised treatment of chronic myeloid leukaemia $(\mathrm{CML})$, cures are rare, because the 'leukaemia stem cells' remain, and a refractory blast crisis can ensue. In a mouse CML model, however, venetoclax plus nilotinib eliminated the leukaemia stem cells and extended mouse survival. ${ }^{100}$ This drug combination even killed human CML cells in blast crisis. ${ }^{100}$ Thus, the efficacy of some $\mathrm{BH} 3$ mimetics may reflect their eradication of 'cancer stem cells'.

Currently, nearly 50 clinical trials of venetoclax are underway in different tumour settings. Although the focus has been on haemopoietic malignancies, trials for solid tumours are eagerly awaited. Pertinently, combining venetoclax with the anti-oestrogen tamoxifen markedly improved responses of $\mathrm{ER}^{+}$breast cancer xenografts that express high BCL-2. ${ }^{101}$ Of greatest moment would be identifying a therapy that eliminated metastasis, the major killer in cancer.

Exciting prospects for targeting MCL-1: Cancer researchers have long sought an effective MCL-1 inhibitor. The elevated MCL-1 found in many tumour types ${ }^{63}$ is implicated in therapy resistance, including of some breast and lung cancers, ${ }^{102,103}$ and many studies ${ }^{68,104,105}$ show that MCL-1 mediates resistance to navitoclax and venetoclax, as their complementary targets suggest (Figures $2 \mathrm{~b}$ and $\mathrm{c}$ ). Most compellingly, conditional gene deletion (or knockdown) demonstrates that $\mathrm{MCL}-1$ is required for the sustained growth of $\mathrm{AML}$ driven by MLL-fusion genes, ${ }^{106}$ MYC-driven $B$ lymphoma, ${ }^{107} \mathrm{TP}^{2} 3^{-1-}$ thymic lymphoma, ${ }^{108}$ BCR-ABLdriven acute lymphoblastic leukaemia ${ }^{109}$ and myeloma. ${ }^{110}$

Valid concerns about the safety of MCL-1 inhibition have arisen from reports of MCL-1 dependence for mouse cardiomyocytes, ${ }^{111}$ hepatocytes ${ }^{112}$ and neurons. ${ }^{113}$ However, $\mathrm{mcl}-1^{+/-}$mice, which should mimic $50 \%$ inhibition, are normal and healthy, suggesting that a suitable therapeutic window may well be found. Furthermore, MCL-1 functions that are independent of $\mathrm{BH} 3$ binding ${ }^{114}$ may contribute to the knockout results. $^{3}$

Developing a specific MCL-1 inhibitor has been challenging, ${ }^{9}$ but very recently three highly potent (subnanomolar) and selective inhibitors have emerged. Preclinical data on the Servier inhibitor S63845 are very impressive. ${ }^{115}$ Notably, $92 \%$ of the multiple myeloma cell lines tested were highly or moderately sensitive, as were $83 \%$ of human lymphoma lines, all tested AML cell lines and half the primary AML samples. This sensitivity translated into markedly extended mouse survival in xenograft and transgenic models. Furthermore, certain solid tumour cell lines, particularly those with low BCL- $\mathrm{X}_{\mathrm{L}}$, were sensitised to conventional therapies. For example, $\mathbf{S} 63845$ showed synergy with current therapies in preclinical models of two types of breast cancer. ${ }^{116}$ Importantly, mice tolerated $\mathbf{S 6 3 8 4 5}$ well, with normal tissues unaffected at doses that eradicated MYC-driven mouse lymphomas. ${ }^{115}$ Thus, a therapeutic window seems likely. Preliminary preclinical reports on the other two new MCL-1 inhibitors are also exciting. Amgen AMG 176 was potent in myeloma, AML and non-Hodgkin's lymphoma cell lines and xenografts, and a phase 1 myeloma trial is underway. ${ }^{117}$ Myeloma was also particularly sensitive to AstraZeneca AZD5991: a single tolerated dose achieved 100\% tumour regression in xenografts. ${ }^{118}$ Clinical findings on the tolerability and efficacy of these three new inhibitors will attract close interest.

Potential of other emerging $\mathrm{BH} 3$ mimetics: Although no trials are underway, a $\mathrm{BCL}-\mathrm{X}_{\mathrm{L}}$-specific $\mathrm{BH} 3$ mimetic may well have clinical utility, as many solid tumours, especially colorectal cancer, ${ }^{119}$ have elevated $B C L-X_{L}$ that correlates with chemoresistance in cancer cell lines. ${ }^{120}$ Selective $B C L-X_{L}$ inhibitors (A-1331852, the most potent) were well tolerated in mice and modestly enhanced docetaxel efficacy against diverse solid tumour xenografts. ${ }^{79}$ As mice lacking one $B C L$ $X_{L}$ allele are healthy ${ }^{121}$ and ramped dosing can largely control the expected thrombocytopaenia, ${ }^{87}$ a therapeutic window for BCL- $X_{L}$ inhibition seems likely.

No specific inhibitors have yet been developed against $B C L$ W, BFL-1 or the little studied BCL-B. BCL-W, recently implicated in maintenance of MYC-driven B lymphomas, ${ }^{122}$ should be a safe target, because $B C L-W^{-1}$ mice are normal, apart from male sterility. ${ }^{123}$ BFL-1 (called A1 in mice) should also be a good target, as it contributes to chemoresistance, ${ }^{105,124}$ and mice lacking all three $\mathrm{A} 1$ isotypes are normal and healthy. ${ }^{125}$

Potential of directly activating $B A X$ or $B A K$ : In principle, any compound directly activating $B A X$ or BAK could be a lead to an effective anticancer agent, given an acceptable therapeutic window. Proof-of-principle studies suggest that compounds engaging either the BAX 'rear' site ${ }^{126}$ or its groove $^{127}$ might have promise, as should other sites driving $\mathrm{BAX}$ or BAK activation, for example, the $a 1-a 2$ loop, ${ }^{128}$ or a site at the junction of the $a 3-a 4$ and $a 5-a 6$ hairpins that sensitises BAX activation. ${ }^{129}$

\section{Concluding remarks}

The remarkable success of $\mathrm{BH} 3$ mimetics has broken new ground in drug development by demonstrating that proteinprotein associations can be targeted with high potency and exquisite specificity, although requiring much larger compounds than enzymes. With highly selective inhibitors now in hand for the three major pro-survival family members, namely BCL-2, BCL- $X_{L}$ and $M C L-1$, cancer researchers and clinicians can rapidly expose the vulnerabilities of multiple cancer types and explore the efficacy of $\mathrm{BH} 3$ mimetics not only as single 
agents but also in combination with each other or with other targeted and conventional agents.

As most, if not all, conventional cytotoxic agents kill through the apoptotic switch governed by the BCL-2 family, what advantages do $\mathrm{BH} 3$ mimetics offer for cancer therapy? First, their direct engagement of the apoptotic machinery is more efficient and selective. Second, because they act downstream of p53 (Figure 1b), even the vast majority of tumours with a defective p53 pathway remain vulnerable. ${ }^{90}$ Third, the oncologist can focus therapy on the pro-survival target(s) to which a particular tumour is 'addicted'. Fourth, at least with CLL, venetoclax responses appear unusually effective and durable, possibly because it can target tumour-initiating cells, as shown for CML. ${ }^{100}$ Fifth, many tumours seem particularly vulnerable to $\mathrm{BH} 3$ mimetics because of their abundant complexes of BH3-only proteins with a pro-survival partner (Figure 4). Sixth, unlike radiotherapy and other DNAdamaging agents, which undoubtedly increase mutational load, BH3 mimetics are not mutagens. Seventh, their mechanism of action is well understood, whereas that of many conventional agents is not. Finally, unlike therapies linked to specific oncogenic mutations or particular cell types, $\mathrm{BH} 3$ mimetics should be relevant to diverse cancers, because they engage a universal apoptotic control mechanism.

We conclude that the advent of $\mathrm{BH} 3$ mimetic drugs represents a notable advance in cancer treatment. Extending their applications to multiple tumour types, including metastatic solid tumours, and optimising their integration with conventional and targeted therapies should lead to greatly protracted remissions and even curative therapies for a number of cancers.

\section{Conflict of Interest}

WEHI has received research funding from Genentech and AbbVie, and royalty and milestone payments for venetoclax.

Acknowledgements. We warmly thank our colleagues at the Walter and Eliza Hall Institute (WEHI) and elsewhere for their many contributions to the research and ideas underpinning this review and apologise to any colleagues whose findings could not be cited because of space constraints. Work in the authors' laboratories was supported by fellowship and grants from the National Health and Medical Research Council (461221, 1016701, 1016647, 1079560, 1041797); SCOR grants (7001-15) from the Leukemia \& Lymphoma Society; and support from the Victorian Cancer Agency, the Cancer Council Victoria; and the Australian Cancer Research Foundation. Research infrastructure at WEHI is supported by annual grants from the governments of Australia (IRIISS Grant 9000220) and Victoria (OIS grant).

1. Croce C. miR15/16 and Bcl2: from gene discovery to treatment. Cell Death Differ 2018; 25: 21-26.

2. Strasser $A$, Vaux DL. Bcl2 and cell death from an evolutionary perspective. Cell Death Differ 2018; 25: 13-20.

3. Opferman J. BCL-2 family in development. Cell Death Differ 2018; 25: 37-45.

4. Andrews DW. Bcl-2 family proteins: Changing partners in the dance towards death. Cell Death Differ 2018; 25: 65-80.

5. Letai A. Why do BCL-2 inhibitors work and where should we use them in the clinic? Cell Death Differ 2018; 25: 56-64.

6. Green DR. MOMP, from cytochrome $\mathrm{c}$ and Smac to unified theory of Bcl-2 function to BAX/ BAK activation to BOK. Cell Death Differ 2018; 25: 46-55.

7. Correia C, Lee SH, Meng XW, Vincelette ND, Knorr KL, Ding $\mathrm{H}$ et al. Emerging understanding of $\mathrm{Bcl}-2$ biology: implications for neoplastic progression and treatment. Biochim Biophys Acta 2015; 1853: 1658-1671.

8. Cory S, Roberts A, Colman PM, Adams JM. Targeting BCL-2-like proteins to kill cancer cells. Trends Cancer 2016; 2: 443-460.
9. Ashkenazi A, Fairbrother WJ, Leverson JD, Souers AJ. From basic apoptosis discoveries to advanced selective BCL-2 family inhibitors. Nat Rev Drug Discov 2017; 16: 273-284.

10. Czabotar PE, Lessene G, Strasser A, Adams JM. Control of apoptosis by the BCL-2 protein family: implications for physiology and therapy. Nat Rev Mol Cell Biol 2014; 15: 49-63.

11. Kerr JFR, Wyllie AH, Currie AR. Apoptosis: a basic biological phenomenon with wideranging implications in tissue kinetics. Br J Cancer 1972; 26: 239-257.

12. Vaux DL, Cory S, Adams JM. Bcl-2 gene promotes haemopoietic cell survival and cooperates with c-myc to immortalize pre-B cells. Nature 1988; 335: 440-442.

13. McDonnell TJ, Deane N, Platt FM, Nuñez G, Jaeger U, McKearn JP et al. bcl-2immunoglobulin transgenic mice demonstrate extended $B$ cell survival and follicular lymphoproliferation. Cell 1989; 57: 79-88.

14. Strasser A, Whittingham S, Vaux DL, Bath ML, Adams JM, Cory S et al. Enforced BCL2 expression in B-lymphoid cells prolongs antibody responses and elicits autoimmune disease. Proc Natl Acad Sci USA 1991; 88: 8661-8665.

15. Sentman CL, Shutter JR, Hockenbery D, Kanagawa O, Korsmeyer SJ. bcl-2 inhibits multiple forms of apoptosis but not negative selection in thymocytes. Cell 1991; 67: 879-888.

16. Strasser A, Harris AW, Cory S. BCl-2 transgene inhibits T cell death and perturbs thymic self-censorship. Cell 1991; 67: 889-899.

17. Strasser A, Harris AW, Bath ML, Cory S. Novel primitive lymphoid tumours induced in transgenic mice by cooperation between myc and bcl-2. Nature 1990; 348: 331-333.

18. Evan Gl, Wyllie AH, Gilbert CS, Littlewood TD, Land H, Brooks M et al. Induction of apoptosis in fibroblasts by c-myc protein. Cell 1992; 69: 119-128.

19. Strasser A, Elefanty AG, Harris AW, Cory S. Progenitor tumours from Em-bcl-2-myc transgenic mice have lymphomyeloid differentiation potential and reveal developmental differences in cell survival. EMBO J 1996; 15: 3823-3834.

20. Limpens J, Stad R, Vos C, de Vlaam C, de Jong D, van Ommen G-JB et al. Lymphomaassociated translocation $t(14 ; 18)$ in blood B cells of normal individuals. Blood 1995; 85 : 2528-2536.

21. Egle A, Harris AW, Bath ML, O'Reilly L, Cory S. VavP-Bcl2 transgenic mice develop follicular lymphoma preceded by germinal center hyperplasia. Blood 2004; 103: 2276-2283.

22. Lindsten T, Ross AJ, King A, Zong W, Rathmell JC, Shiels HA et al. The combined functions of proapoptotic Bcl-2 family members Bak and Bax are essential for normal development of multiple tissues. Mol Cell 2000; 6: 1389-1399.

23. Strasser A, Cory S, Adams JM. Deciphering the rules of programmed cell death to improve therapy of cancer and other diseases. EMBO J 2011; 30: 3667-3683.

24. Happo L, Strasser A, Cory S. BH3-only proteins in apoptosis at a glance. J Cell Sci 2012; 125: $1081-1087$

25. Egle A, Harris AW, Bouillet $P$, Cory S. Bim is a suppressor of Myc-induced mouse $B$ cell leukemia. Proc Natl Acad Sci USA 2004; 101: 6164-6169.

26. Muchmore SW, Sattler M, Liang H, Meadows RP, Harlan JE, Yoon HS et al. X-ray and NMR structure of human Bcl- $\mathrm{X}_{\mathrm{L}}$, an inhibitor of programmed cell death. Nature 1996; 381: 335-341.

27. Liu X, Dai S, Zhu Y, Marrack $P$, Kappler JW. The structure of a $B c l-x_{L} / B i m$ fragment complex: Implications for Bim function. Immunity 2003; 19: 341-352.

28. Suzuki M, Youle RJ, Tjandra N. Structure of Bax: coregulation of dimer formation and intracellular localization. Cell 2000; 103: 645-654.

29. Kvansakul M, Hinds MG. The Bcl-2 family: structures, interactions and targets for drug discovery. Apoptosis 2015; 20: 136-150.

30. Sattler M, Liang H, Nettesheim D, Meadows RP, Harlan JE, Eberstadt M et al. Structure of Bcl-X $\mathrm{X}_{\mathrm{L}}$-Bak peptide complex: recognition between regulators of apoptosis. Science 1997; 275: 983-986.

31. Opferman JT, Letai A, Beard C, Sorcinelli MD, Ong CC, Korsmeyer SJ. Development and maintenance of B and T lymphocytes requires antiapoptotic MCL-1. Nature 2003; 426: 671-676.

32. Chen L, Willis SN, Wei A, Smith BJ, Fletcher JI, Hinds MG et al. Differential targeting of prosurvival $\mathrm{Bcl}-2$ proteins by their $\mathrm{BH} 3$-only ligands allows complementary apoptotic function. Mol Cell 2005; 17: 393-403.

33. Kuwana T, Bouchier-Hayes L, Chipuk JE, Bonzon C, Sullivan BA, Green DR et al. BH3 domains of BH3-only proteins differentially regulate Bax-mediated mitochondrial membrane permeabilization both directly and indirectly. Mol Cell 2005; 17: 525-535.

34. Willis SN, Chen L, Dewson G, Wei A, Naik E, Fletcher Jl et al. Proapoptotic Bak is sequestered by $\mathrm{Mcl}-1$ and $\mathrm{Bcl}-\mathrm{xL}$, but not $\mathrm{Bcl}-2$, until displaced by $\mathrm{BH} 3$-only proteins. Genes Dev 2005; 19: 1294-1305.

35. Willis SN, Fletcher Jl, Kaufmann T, van Delft MF, Chen L, Czabotar PE et al. Apoptosis initiated when $\mathrm{BH} 3$ ligands engage multiple Bcl-2 homologs, not Bax or Bak. Science 2007; 315: 856-859.

36. Edlich F, Banerjee S, Suzuki M, Cleland MM, Arnoult D, Wang C et al. Bcl-x $(L)$ retrotranslocates Bax from the mitochondria into the cytosol. Cell 2011; 145: 104-116.

37. Todt F, Cakir Z, Reichenbach F, Emschermann F, Lauterwasser J, Kaiser A et al. Differential retrotranslocation of mitochondrial Bax and Bak. EMBO J 2015; 34: 67-80.

38. Cheng EH, Sheiko TV, Fisher JK, Craigen WJ, Korsmeyer SJ. VDAC2 inhibits BAK activation and mitochondrial apoptosis. Science 2003; 301: 513-517.

39. Roy SS, Ehrlich AM, Craigen WJ, Hajnoczky G. VDAC2 is required for truncated BIDinduced mitochondrial apoptosis by recruiting BAK to the mitochondria. EMBO Rep 2009; 10: $1341-1347$.

40. Ma SB, Nguyen TN, Tan I, Ninnis R, lyer S, Stroud DA et al. Bax targets mitochondria by distinct mechanisms before or during apoptotic cell death: a requirement for VDAC2 or Bak for efficient Bax apoptotic function. Cell Death Differ 2014; 21: 1925-1935. 
41. Czabotar PE, Westphal D, Dewson G, Ma S, Hockings C, Fairlie WD et al. Bax crystal structures reveal how $\mathrm{BH} 3$ domains activate $\mathrm{Bax}$ and nucleate its oligomerization to induce apoptosis. Cell 2013; 152: 519-531.

42. Moldoveanu T, Grace CR, Llambi F, Nourse A, Fitzgerald P, Gehring K et al. BID-induced structural changes in BAK promote apoptosis. Nat Struct Mol Biol 2013; 20: 589-597.

43. Brouwer JM, Westphal D, Dewson G, Robin AY, Uren RT, Bartolo R et al. Bak core and latch domains separate during activation, and freed core domains form symmetric homodimers. Mol Cell 2014; 55: 938-946.

44. Robin AY, Krishna Kumar K, Westphal D, Wardak AZ, Thompson GV, Dewson G et al. Crystal structure of Bax bound to the BH3 peptide of Bim identifies important contacts for interaction. Cell Death Dis 2015; 6: e1809.

45. Alsop AE, Fennell SC, Bartolo RC, Tan IK, Dewson G, Kluck RM. Dissociation of Bak alpha1 helix from the core and latch domains is required for apoptosis. Nat Commun 2015; 6: 6841

46. Dewson G, Kratina T, Sim HW, Puthalakath H, Adams JM, Colman PM et al. To trigger apoptosis Bak exposes its $\mathrm{BH} 3$ domain and homo-dimerizes via $\mathrm{BH} 3$ :grooove interactions. Mol Cell 2008; 30: 369-380.

47. Dewson G, Ma S, Frederick P, Hockings C, Tan I, Kratina T et al. Bax dimerizes via a symmetric BH3:groove interface during apoptosis. Cell Death Differ 2012; 19: 661-670.

48. O'Neill KL, Huang K, Zhang J, Chen Y, Luo X. Inactivation of prosurvival Bcl-2 proteins activates Bax/Bak through the outer mitochondrial membrane. Genes Dev 2016; 30: 973-988.

49. George NM, Evans JJ, Luo X. A three-helix homo-oligomerization domain containing $\mathrm{BH} 3$ and $\mathrm{BH} 1$ is responsible for the apoptotic activity of Bax. Genes Dev 2007; 21: 1937-1948.

50. Dewson G, Kratina T, Czabotar P, Day CL, Adams JM, Kluck RM. Bak activation for apoptosis involves oligomerization of dimers via their alpha6 helices. Mol Cell 2009; 36: 696-703.

51. Ma S, Hockings C, Anwari K, Kratina T, Fennell S, Lazarou M et al. Assembly of the Bak apoptotic pore: a critical role for the Bak protein alpha6 helix in the multimerization of homodimers during apoptosis. J Biol Chem 2013; 288: 26027-26038.

52. Aluvila S, Mandal T, Hustedt E, Fajer $\mathrm{P}$, Choe JY, Oh KJ. Organization of the mitochondrial apoptotic BAK pore: oligomerization of the BAK homodimers. J Biol Chem 2014; 289: 2537-2551.

53. Iyer S, Bell F, Westphal D, Anwari K, Gulbis J, Smith BJ et al. Bak apoptotic pores involve a flexible C-terminal region and juxtaposition of the $\mathrm{C}$-terminal transmembrane domains. Cell Death Differ 2015; 22: 1665-1675.

54. Zhang Z, Subramaniam S, Kale J, Liao C, Huang B, Brahmbhatt $\mathrm{H}$ et al. BH3-in-groove dimerization initiates and helix 9 dimerization expands Bax pore assembly in membranes. EMBO J 2016; 35: 208-236.

55. Uren RT, O'Hely M, lyer S, Bartolo R, Shi MX, Brouwer JM et al. Disordered clusters of Bak dimers rupture mitochondria during apoptosis. Elife 2017; 6: e19944.

56. Westphal D, Dewson G, Menard M, Frederick P, lyer S, Bartolo R et al. Apoptotic pore formation is associated with in-plane insertion of Bak or Bax central helices into the mitochondrial outer membrane. Proc Natl Acad Sci USA 2014; 111: E4076-E4085.

57. Bleicken S, Jeschke G, Stegmueller C, Salvador-Gallego R, Garcia-Saez AJ, Bordignon E. Structural model of active Bax at the membrane. Mol Cell 2014; 56: 496-505.

58. Uren RT, lyer S, Kluck RM. Pore formation by dimeric Bak and Bax: an unusual pore? Philos Trans R Soc Lond B Biol Sci 2017; 372: 1726.

59. Annis MG, Soucie EL, Dlugosz PJ, Cruz-Aguado JA, Penn LZ, Leber B et al. Bax forms multispanning monomers that oligomerize to permeabilize membranes during apoptosis. EMBO J 2005; 24: 2096-2103.

60. Kuwana T, Olson NH, Kiosses WB, Peters B, Newmeyer DD. Pro-apoptotic Bax molecules densely populate the edges of membrane pores. Sci Rep 2016; 6: 27299

61. Salvador-Gallego R, Mund M, Cosentino K, Schneider J, Unsay J, Schraermeyer U et al. Bax assembly into rings and arcs in apoptotic mitochondria is linked to membrane pores. EMBO J 2016; 35: 389-401.

62. Grosse L, Wurm CA, Bruser C, Neumann D, Jans DC, Jakobs S. Bax assembles into large ring-like structures remodeling the mitochondrial outer membrane in apoptosis. EMBO J 2016; 35: 402-413.

63. Beroukhim R, Mermel C, Porter D, Wei G, Raychaudhuri S, Donovan J et al. The landscape of somatic copy-number alteration across human cancers. Nature 2010; 463: 899-905.

64. Villunger A, Michalak EM, Coultas L, Mullauer F, Bock G, Ausserlechner MJ et al. p53- and drug-induced apoptotic responses mediated by $\mathrm{BH}$-only proteins puma and noxa. Science 2003; 302: 1036-1038.

65. Tagawa H, Karnan S, Suzuki R, Matsuo K, Zhang X, Ota A et al. Genome-wide array-based CGH for mantle cell lymphoma: identification of homozygous deletions of the proapoptotic gene BIM. Oncogene 2005; 24: 1348-1358.

66. Garrison SP, Jeffers JR, Yang C, Nilsson JA, Hall MA, Rehg JE et al. Selection against PUMA gene expression in Myc-driven B-cell lymphomagenesis. Mol Cell Biol 2008; 28 : 5391-5402.

67. Richter-Larrea JA, Robles EF, Fresquet V, Beltran E, Rullan AJ, Agirre X et al. Reversion of epigenetically mediated BIM silencing overcomes chemoresistance in Burkitt lymphoma. Blood 2010; 116: 2531-2542.

68. van Delft MF, Wei AH, Mason KD, Vandenberg CJ, Chen L, Czabotar PE et al. The BH3 mimetic ABT-737 targets selective $\mathrm{Bcl}-2$ proteins and efficiently induces apoptosis via Bak/ Bax if Mcl-1 is neutralized. Cancer Cell 2006; 10: 389-399.

69. Lessene G, Czabotar PE, Colman PM. BCL-2 family antagonists for cancer therapy. Nat Rev Drug Discov 2008; 7: 989-1000.
70. Oltersdorf T, Elmore SW, Shoemaker AR, Armstrong RC, Augeri DJ, Belli BA et al. An inhibitor of Bcl-2 family proteins induces regression of solid tumours. Nature 2005; 435 677-681.

71. Tse C, Shoemaker AR, Adickes J, Anderson MG, Chen J, Jin S et al. ABT-263: a potent and orally bioavailable Bcl-2 family inhibitor. Cancer Res 2008; 68: 3421-3428.

72. Lee EF, Czabotar PE, Smith BJ, Deshayes K, Zobel K, Colman PM et al. Crystal structure of ABT-737 complexed with Bcl-x(L): implications for selectivity of antagonists of the Bcl2 family. Cell Death Differ 2007; 14: 1711-1713.

73. Souers AJ, Leverson JD, Boghaert ER, Ackler SL, Catron ND, Chen J et al. ABT-199, a potent and selective BCL-2 inhibitor, achieves antitumor activity while sparing platelets. Nat Med 2013; 19: 202-208.

74. Mason KD, Carpinelli MR, Fletcher JI, Collinge JE, Hilton AA, Ellis S et al. Programmed anuclear cell death delimits platelet life span. Cell 2007; 128: 1173-1186.

75. Roberts AW, Seymour JF, Brown JR, Wierda WG, Kipps TJ, Khaw SL et al. Substantial susceptibility of chronic lymphocytic leukemia to BCL2 inhibition: results of a phase i study of navitoclax in patients with relapsed or refractory disease. J Clin Oncol 2012; 30 488-496.

76. Wilson WH, O'Connor OA, Czuczman MS, Lacasce AS, Gerecitano JF, Leonard JP et al. Navitoclax, a targeted high-affinity inhibitor of BCL-2, in lymphoid malignancies: a phase 1 dose-escalation study of safety, pharmacokinetics, pharmacodynamics, and antitumour activity. Lancet Oncol 2010; 11: 1149-1159.

77. Vandenberg CJ, Cory S. ABT-199 a new Bcl-2-specific BH3 mimetic, has in vivo efficacy against aggressive Myc-driven mouse lymphomas without provoking thrombocytopenia Blood 2013; 121: 2285-2288.

78. Lessene G, Czabotar PE, Sleebs BE, Zobel K, Lowes KL, Adams JM et al. Structureguided design of a selective BCL-XL inhibitor. Nat Chem Biol 2013; 9: 390-397.

79. Leverson JD, Phillips DC, Mitten MJ, Boghaert ER, Diaz D, Tahir SK et al. Exploiting selective BCL-2 family inhibitors to dissect cell survival dependencies and define improved strategies for cancer therapy. Sci Transl Med 2015; 7: 279ra240.

80. Certo M, Moore Vdel G, Nishino M, Wei G, Korsmeyer S, Armstrong SA et al. Mitochondria primed by death signals determine cellular addiction to antiapoptotic BCL-2 family members. Cancer Cell 2006; 9: 351-365.

81. Del Gaizo Moore V, Brown JR, Certo M, Love TM, Novina CD, Letai A. Chronic lymphocytic leukemia requires $B C L 2$ to sequester prodeath $B I M$, explaining sensitivity to $B C L 2$ antagonist ABT-737. J Clin Invest 2007; 117: 112-121.

82. Merino D, Khaw SL, Glaser SP, Anderson DJ, Belmont LD, Wong C et al. Bcl-2, Bcl-x(L), and $\mathrm{Bcl}-\mathrm{w}$ are not equivalent targets of ABT-737 and navitoclax (ABT-263) in lymphoid and leukemic cells. Blood 2012; 119: 5807-5816.

83. Chonghaile TN, Sarosiek KA, Vo TT, Ryan JA, Tammareddi A, Moore VD et al. Pretreatment mitochondrial priming correlates with clinical response to cytotoxic chemotherapy. Science 2011; 334: 1129-1133.

84. Vo TT, Ryan J, Carrasco R, Neuberg D, Rossi DJ, Stone RM et al. Relative mitochondrial priming of myeloblasts and normal HSCs determines chemotherapeutic success in AML. Cell 2012; 151: 344-355.

85. Sarosiek KA, Fraser C, Muthalagu N, Bhola PD, Chang W, McBrayer SK et al. Developmental regulation of mitochondrial apoptosis by c-Myc governs age- and tissuespecific sensitivity to cancer therapeutics. Cancer Cell 2017; 31: 142-156.

86. Mason KD, Vandenberg CJ, Scott CL, Wei AH, Cory S, Huang DC et al. In vivo efficacy of the Bcl-2 antagonist ABT-737 against aggressive Myc-driven lymphomas. Proc Natl Acad Sci USA 2008; 105: 17961-17966.

87. Roberts AW, Advani RH, Kahl BS, Persky D, Sweetenham JW, Carney DA et al. Phase 1 study of the safety, pharmacokinetics, and antitumour activity of the BCL2 inhibitor navitoclax in combination with rituximab in patients with relapsed or refractory $\mathrm{CD} 20+$ lymphoid malignancies. Br J Haematol 2015; 170: 669-678.

88. Roberts AW, Davids MS, Pagel JM, Kahl BS, Puvvada SD, Gerecitano JF et al. Targeting BCL2 with venetoclax in relapsed chronic lymphocytic leukemia. N Engl J Med 2016; 374: 311-322.

89. Stilgenbauer S, Eichhorst B, Schetelig J, Coutre S, Seymour JF, Munir T et al. Venetoclax in relapsed or refractory chronic lymphocytic leukaemia with $17 p$ deletion: a multicentre open-label, phase 2 study. Lancet Oncol 2016; 17: 768-778.

90. Anderson MA, Deng J, Seymour JF, Tam C, Kim SY, Fein J et al. The BCL2 selective inhibitor venetoclax induces rapid onset apoptosis of CLL cells in patients via a TP53independent mechanism. Blood 2016; 127: 3215-3224.

91. Davids MS, Roberts AW, Seymour JF, Pagel JM, Kahl BS, Wierda WG et al. Phase I firstin-human study of venetoclax in patients with relapsed or refractory non-Hodgkin lymphoma. J Clin Oncol 2017; 35: 826-833.

92. Roberts AW, Huang D. Targeting BCL2 with $\mathrm{BH} 3$ mimetics: basic science and clinical application of venetoclax in chronic lymphocytic leukemia and related $B$ cell malignancies. Clin Pharmacol Ther 2017; 101: 89-98.

93. Konopleva M, Pollyea DA, Potluri J, Chyla B, Hogdal L, Busman T et al. Efficacy and biological correlates of response in a phase II study of venetoclax monotherapy in patients with acute myelogenous leukemia. Cancer Discov 2016; 6: 1106-1117.

94. Matulis SM, Gupta VA, Nooka AK, Hollen HV, Kaufman JL, Lonial S et al. Dexamethasone treatment promotes $\mathrm{Bcl}-2$ dependence in multiple myeloma resulting in sensitivity to venetoclax. Leukemia 2016; 30: 1086-1093.

95. Cervantes-Gomez F, Lamothe B, Woyach JA, Wierda WG, Keating MJ, Balakrishnan K et al. Pharmacological and protein profiling suggests venetoclax (ABT-199) as optimal 
partner with ibrutinib in chronic lymphocytic leukemia. Clin Cancer Res 2015; 21 : 3705-3715.

96. Seymour JF, Ma S, Brander DM, Choi MY, Barrientos J, Davids MS et al. Venetoclax plus rituximab in relapsed or refractory chronic lymphocytic leukaemia: a phase $1 \mathrm{~b}$ study. Lancet Oncol 2017; 18: 230-240.

97. Pollyea DA, Di Nardo C, Thirman M, Letai A, Wei A, Jonas BA et al. Results of a phase $1 \mathrm{~b}$ study of venetoclax plus decitabine or azacitidine in untreated acute myeloid leukemia patients $>=65$ years ineligible for standard induction therapy. Haematologica 2016; 101 (Supplement): 44-44.

98. Teh TC, Nguyen NY, Moujalled DM, Segal D, Pomilio G, Rijal S et al. Enhancing venetoclax activity in acute myeloid leukemia by co-targeting MCL1. Leukemia 2017.

99. Chan SM, Thomas D, Corces-Zimmerman MR, Xavy S, Rastogi S, Hong WJ et al. Isocitrate dehydrogenase 1 and 2 mutations induce $\mathrm{BCL}-2$ dependence in acute myeloid leukemia. Nat Med 2015; 21: 178-184.

100. Carter BZ, Mak PY, Mu H, Zhou H, Mak DH, Schober W et al. Combined targeting of BCL-2 and BCR-ABL tyrosine kinase eradicates chronic myeloid leukemia stem cells. Sci Trans Med 2016; 8: 355ra117.

101. Vaillant $F$, Merino D, Lee L, Breslin K, Pal B, Ritchie ME et al. Targeting BCL-2 with the BH3 mimetic ABT-199 in estrogen receptor-positive breast cancer. Cancer Cell 2013; 24: 120-129.

102. Zhang H, Guttikonda S, Roberts L, Uziel T, Semizarov D, Elmore SW et al. Mcl-1 is critical for survival in a subgroup of non-small-cell lung cancer cell lines. Oncogene 2011; 30 : 1963-1968.

103. Xiao $Y$, Nimmer $P$, Sheppard GS, Bruncko M, Hessler $P$, Lu $X$ et al. MCL-1 Is a key determinant of breast cancer cell survival: validation of $\mathrm{MCL}-1$ dependency utilizing a highly selective small molecule inhibitor. Mol Cancer Ther 2015; 14: 1837-1847.

104. Leverson JD, Zhang H, Chen J, Tahir SK, Phillips DC, Xue J et al. Potent and selective small-molecule MCL-1 inhibitors demonstrate on-target cancer cell killing activity as single agents and in combination with ABT-263 (navitoclax). Cell Death Dis 2015; 6: e1590.

105. Yecies D, Carlson NE, Deng J, Letai A. Acquired resistance to ABT-737 in lymphoma cells that up-regulate MCL-1 and BFL-1. Blood 2010; 115: 3304-3313.

106. Glaser S, Lee EF, Trounson E, Bouillet P, Wei A, Fairlie WD et al. Anti-apoptotic Mcl-1 is essential for the development and sustained growth of acute myeloid leukemia. Genes Dev 2012; 26: 120-125.

107. Kelly GL, Grabow S, Glaser SP, Fitzsimmons L, Aubrey BJ, Okamoto T et al. Targeting of MCL-1 kills MYC-driven mouse and human lymphomas even when they bear mutations in p53. Genes Dev 2014; 28: 58-70.

108. Grabow S, Delbridge AR, Valente LJ, Strasser A. MCL-1 but not BCL-XL is critical for the development and sustained expansion of thymic lymphoma in p53-deficient mice. Blood 2014; 124: 3939-3946.

109. Koss B, Morrison J, Perciavalle RM, Singh H, Rehg JE, Williams RT et al. Requirement for antiapoptotic MCL-1 in the survival of BCR-ABL B-lineage acute lymphoblastic leukemia. Blood 2013; 122: 1587-1598.

110. Gong JN, Khong T, Segal D, Yao Y, Riffkin CD, Garnier JM et al. Hierarchy for targeting prosurvival BCL2 family proteins in multiple myeloma: pivotal role of MCL1. Blood 2016; 128: 1834-1844.

111. Thomas RL, Roberts DJ, Kubli DA, Lee Y, Quinsay MN, Owens JB et al. Loss of MCL-1 leads to impaired autophagy and rapid development of heart failure. Genes Dev 2013; 27: 1365-1377.

112. Vick B, Weber A, Urbanik T, Maass T, Teufel A, Krammer PH et al. Knockout of myeloid cell leukemia-1 induces liver damage and increases apoptosis susceptibility of murine hepatocytes. Hepatology 2009; 49: 627-636.

113. Arbour N, Vanderluit JL, Le Grand JN, Jahani-Asl A, Ruzhynsky VA, Cheung EC et al. Mcl-1 is a key regulator of apoptosis during CNS development and after DNA damage. $J$ Neurosci 2008; 28: 6068-6078.

114. Perciavalle RM, Stewart DP, Koss B, Lynch J, Milasta S, Bathina M et al. Anti-apoptotic MCL-1 localizes to the mitochondrial matrix and couples mitochondrial fusion to respiration. Nat Cell Biol 2012; 14: 575-583.

115. Kotschy A, Szlavik Z, Murray J, Davidson J, Maragno AL, Le Toumelin-Braizat G et al. The MCL1 inhibitor S63845 is tolerable and effective in diverse cancer models. Nature 2016; 538: 477-482.
116. Merino D, Whittle JR, Vaillant F, Serrano A, Gong JN, Giner G et al. Synergistic action of the MCL-1 inhibitor $S 63845$ with current therapies in preclinical models of triple-negative and HER2-amplified breast cancer. Sci Transl Med 2017; 9: 401.

117. Hughes PE The discovery and preclinical characterization of AMG 176: a first-in-class Mcl1 inhibitor in clinical development for multiple myeloma. Proceedings: American Association for Cancer Research Annual Meeting, Washington, DC 2017 Abstract DDT01-01.

118. Hird AW, Secrist JP, Adam A, Belmonte MA, Gangl E, Gibbons F et al. AZD5991: a potent and selective macrocyclic inhibitor of Mcl-1 for treatment of hematologic cancers. Proceedings: American Association for Cancer Research Annual Meeting, 2017. Abstract DDT01-02.

119. Zhang H, Xue J, Hessler P, Tahir SK, Chen J, Jin S et al. Genomic analysis and selective small molecule inhibition identifies $B C L-X(L)$ as a critical survival factor in a subset of colorectal cancer. Mol Cancer 2015; 14: 126.

120. Amundson SA, Myers TG, Scudiero D, Kitada S, Reed JC, Fornace AJ Jr. An informatics approach identifying markers of chemosensitivity in human cancer cell lines. Cancer Res 2000; 60: 6101-6110.

121. Kasai S, Chuma S, Motoyama N, Nakatsuji N. Haploinsufficiency of Bcl-x leads to malespecific defects in fetal germ cells: differential regulation of germ cell apoptosis between the sexes. Dev Biol 2003; 264: 202-216.

122. Adams CM, Kim AS, Mitra R, Choi JK, Gong JZ, Eischen CM. BCL-W has a fundamental role in B cell survival and lymphomagenesis. J Clin Invest 2017; 127: 635-650.

123. Print CG, Loveland KL, Gibson L, Meehan T, Stylianou A, Wreford N et al. Apoptosis regulator Bcl-w is essential for spermatogenesis but appears otherwise redundant. Proc Natl Acad Sci USA 1998; 95: 12424-12431.

124. Brien G, Trescol-Biemont MC, Bonnefoy-Berard N. Downregulation of Bfl-1 protein expression sensitizes malignant B cells to apoptosis. Oncogene 2007; 26: 5828-5832.

125. Schenk RL, Tuzlak S, Carrington EM, Zhan Y, Heinzel S, Teh CE et al. Characterisation of mice lacking all functional isoforms of the pro-survival BCL-2 family member A1 reveals minor defects in the haematopoietic compartment. Cell Death Differ 2017; 24: 534-545.

126. Gavathiotis E, Reyna DE, Bellairs JA, Leshchiner ES, Walensky LD. Direct and selective small-molecule activation of proapoptotic BAX. Nat Chem Biol 2012; 8: 639-645.

127. Zhao G, Zhu Y, Eno CO, Liu Y, Deleeuw L, Burlison JA et al. Activation of the proapoptotic Bcl-2 protein Bax by a small molecule induces tumor cell apoptosis. Mol Cell Biol 2014; 34: 1198-1207.

128. Iyer S, Anwari K, Alsop AE, Yuen WS, Huang DC, Carroll J et al. Identification of an activation site in Bak and mitochondrial Bax triggered by antibodies. Nat Commun 2016; 7: 11734.

129. Pritz JR, Wachter F, Lee S, Luccarelli J, Wales TE, Cohen DT et al. Allosteric sensitization of proapoptotic BAX. Nat Chem Biol 2017; 13: 961-967.

130. Gavathiotis E, Suzuki M, Davis ML, Pitter K, Bird GH, Katz SG et al. BAX activation is initiated at a novel interaction site. Nature 2008; 455: 1076-1081.

131. Gavathiotis E, Reyna DE, Davis ML, Bird GH, Walensky LD. BH3-triggered structural reorganization drives the activation of proapoptotic BAX. Mol Cell 2010; 40: 481-492.

132. Bleicken S, Classen M, Padmavathi PV, Ishikawa T, Zeth K, Steinhoff HJ et al. Molecular details of Bax activation, oligomerization, and membrane insertion. J Biol Chem 2010; 285 : $6636-6647$.

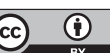

This work is licensed under a Creative Commons Attribution 4.0 International License. The images or other third party material in this article are included in the article's Creative Commons license, unless indicated otherwise in the credit line; if the material is not included under the Creative Commons license, users will need to obtain permission from the license holder to reproduce the material. To view a copy of this license, visit http:// creativecommons.org/licenses/by/4.0/

(C) The Author(s) 2018 